W.C.2. Completed applications should be returned to the Registrar not later than January 31 .

\section{Interdisciplinary Conference on Self-Organizing Systems}

AN Interdisciplinary Conference on Self-Organizing Systems will be held on May 5 and 6 at the Museum of Science and Industry, Chicago, Illinois. The conference is to be co-sponsored by the Information Systems Branch of the Office of Naval Research and the Armour Research Foundation. The purpose of this conference is to bring together research workers in all fields of science who are concerned either with the development of self-adaptive information systems or with the conduct of research which may contribute to an improved understanding of cognitive, learning, and growth processes. Particular emphasis will be placed on theoretical models of systems which are capable of spontancous classification, identification and symbolization of their inputs. Further information can be obtained from Mr. Scott Cameron, Conference Secretary, Armour Research Foundation, 10 West 35th Street, Chicago 16, Illinois.

\section{Centenary of the Royal Society of Victoria}

To mark the publication of Darwin's "Origin of Species" in November 1859, and the granting in the same month of the royal title to the Royal Society of Victoria, Australia, this Society will hold a symposium on "The Evolution of Living Organisms" during December 7-1 1, 1959. Dr. Ernst Mayr, of the United States, will be the principal speaker, and the symposium will open with a Tiegs Memorial Lecture in memory of Prof. O. W. Tiegs.

\section{University News: \\ Belfast}

THE following appointments have recently been made in The Queen's University of Belfast : G. C. R. Carey, to a lectureship in preventive medicine; Dr. G. S. Higginson, to a supernumerary lectureship in physies.

London

The title of reader in the University of London has been conferred on Dr. D. D. Davies (in plant biochemistry) in respect of his post at King's College ; and on Dr. J. L. Mongar (in chemical pharmacology) in respect of his post at University College.

Pittsburgh

ThIRTX-Two grants totalling 630,766 dollars have been awarded to the Division of the Natural Sciences of the University of Pittsburgh, Pennsylvania. Among the principal grants received since July 1, 1958 , by six departments of the Division and the Radiation Laboratory are the following: 75,000 dollars to R. A. McConnell (assistant research professor, Department of Biophysics), from the A. W. Mellon Educational and Charitable Trust to continue research on psychological physics; 23,000 dollars to Dr. G. Felsenfeld (assistant professor, Department of Biophysics), from the National Science Foundation to initiate research on the active site in some coppercarrying proteins; 25,421 dollars to Prof. W. E. Wallace (Department of Chemistry), from the U.S. Atomic Energy Commission to continue an investigation of the application of chemical thermodynamics to study the formation of metallic alloys; 41,600 dollars to Dr. T. M. Donahue (associate professor, Department of Physics), from the Office of Naval
Research to continue studies on capture-loss and ionization cross-sections of ions and neutral particles ; 40,360 dollars to Prof. G. J. Wischner (Depart. ment of Psychology), from the National Institute of Mental Health to continue graduate training in clinical psychology ; 129,000 dollars to Prof. A. J. Allen (director of the Radiation Laboratory), from the Office of Naval Research to continue research on precision scattering of nuclear particles; 38,415 dollars to Prof. G. A. Jeffrey (Radiation Laboratory), from the Air Force Office of Scientific Research to initiate research on the structure of crystalline hydrates of organic molecules and ions; 27,243 dollars to Prof. L. A. Page (Radiation Laboratory), from the U.S. Army Office of Ordnance Research to begin a research programme on low-energy nuclear and electron physics.

\section{Announcements}

Prof. Chien-Shiung Wu, professor of physics in Columbia University, New York, is to be awarded the 1958 Research Corporation Award for her valuable contribution to the knowledge of beta-decay and particularly for her part in research which resulted in the overthrow of the conservation of parity. She will receive an honorarium of 2,500 dollars, a plaque and a citation.

THE following have been appointed to fill vacancies on the University Grants Committee: Dr. Kitty Anderson, head mistress, North London Collegiate School ; Prof. Asa Briggs, professor of modern history, University of Leeds ; Prof. F. A. Vick, professor of physics, University College of North Staffordshire ; Dr. K. C. Wheare, rector of Exeter College, Oxford.

The symposium on "The Nature of Coal" organ. ized by the Central Fuel Research Institute, India, will now be held during February 7-9, instead of during February $9-11$, as was announced earlier (see Nature, 182, 295 ; 1958).

Between January 13 and March 17, the Department of Chemistry, Biology and Geology of the Kingston Technical College is holding a postgraduate lecture course on "Recent Advances in Protein Chemistry", with lecturers well known for their work in this field. Further information can be obtained from the Head of the Department at the Kingston Technical College, Fassett Road, Kingstonupon-Thames.

ON February 6 the Scottish Branch of Aslib will hold its annual general meeting and conference in Glasgow. The theme of the morning session is patents, and that of the afternoon, mutual co-operation. The morning speakers will be Mr. Felix Liebesny on "Patents as Sources of Information", and Mr. Christopher Johnson on "Trade Marks and Industrial Designs, their History, Development and Protection". The afternoon speakers will be Mr. E. Martindale, of the Department of Scientific and Industrial Research, who will speak on the Scottish Research Laboratories Mutual Assistance Scheme, and, it is hoped, Prof. Christopher Macrae, from the Regional Technical Liaison Service of the Department.

Is the communication entitled "Thermal Annealing of Chemical Radiation Damage" by Dr. A. G. Maddock and S. R. Mohanty in Nature of December 27, p. 1797, the graph refers to isothermal annealing at $150^{\circ} \mathrm{C}$. 